\title{
Repeat the Memory Phrase
}

National Cancer Institute

\section{Source}

National Cancer Institute. Repeat the Memory Phrase. NCI Thesaurus. Code C110934.

A request that an individual repeat a memory phrase. 